\title{
Serum and follicular fluid Anti-Mullerian hormone concentrations at the time of follicle puncture and reproductive outcome
}

\author{
Follikül aspirasyon zamanı serum ve follikül sıvısında Anti-Mullerian hormon \\ konsantrasyonu ve reprodüktif sonuçlar
}

\author{
Selma İnat Çapkın, Şebnem Özyer, Rana Karayalçın, Özlem Moraloğlu, Sarp Özcan, Mustafa Uğur \\ Zekai Tahir Burak Women's Health Education and Research Hospital, IVf Unit, Ankara, Turkey
}

\section{Abstract}

Objective: The objective of the study is to determine and compare the levels of Anti-Mullerian hormone (AMH) and estradiol (E2) in serum and follicular fluid (FF) on the day of oocyte pick up (OPU) with the cycle parameters and the outcome of in vitro fertilization (IVF) treatment.

Material and Methods: The long stimulation protocol was used in 37 (86\%) women; the microdose flare-up protocol was used in $6(14 \%)$ women. Concentrations of AMH and E2 were measured in serum and FF of 43 women undergoing IVF treatment on the day of OPU.

Results: Significant positive associations were observed between serum AMH concentrations and the total number of oocytes retrieved $(\mathrm{r}=0.343, \mathrm{p}=0.024)$. Serum AMH and FF AMH levels on the day of OPU were significantly increased in the group of women who achieved clinical pregnancy $(p=0.017, p=0.028)$. For serum AMH, a cut-off level of $1.64 \mathrm{ng} / \mathrm{ml}$ was used for the prediction of clinical pregnancy; for FF $\mathrm{AMH}$, a cut-off level of $3.8 \mathrm{ng} / \mathrm{ml}$ was used for the prediction of clinical pregnancy. Serum AMH and FF AMH levels were significantly and positively correlated with implantation rate $(\mathrm{r}=0.401, \mathrm{p}=0.008 ; \mathrm{r}=0.317$, $p=0.039$ ). No significant correlation was found between serum and FF AMH concentrations and fertilization rate.

Conclusion: Serum AMH and FF AMH concentrations are positively correlated with implantation and clinical pregnancy rates.

(J Turkish-German Gynecol Assoc 2012; 13: 21-6)

Key words: AMH, E2, follicular fluid, IVF

Received: 15 September, 2011

Accepted: 19 October, 2011

\section{Özet}

Amaç: Çalışmanın amacı oosit aspirasyon günü serum ve follikül sıvisinda Anti-Mullerian hormon (AMH) ve estradiol seviyelerini saptamak ve siklus parametreleri ve in vitro fertilizasyon tedavisi sonuçları ile karşılaştırmaktır.

Gereç ve Yöntemler: Otuz yedi (\%86) hastada long stimulasyon, 6 (\%14) hastada mikrodoz flare-up protokol uygulanmıştır. Oosit aspirasyon günü in vitro fertilizasyon tedavisi alan 43 hastanın serum ve follikül sıvısında AMH ve estradiol konsantrasyonlanı saptanmıştır.

Bulgular: Serum AMH konsantrasyonları ve toplanan oosit sayları arasında anlamlı pozitif ilişki saptanmıştır $(r=0.343, p=0.024)$. Oosit aspirasyon günü serum AMH ve follikül sıvısı AMH seviyeleri klinik gebelik saptanan hastalarda anlamlı olarak yüksek bulunmuştur $(\mathrm{p}=0.017, \mathrm{p}=0.028)$. Serum AMH için $1.64 \mathrm{ng} / \mathrm{ml}$, follikül sıvısı için $3.8 \mathrm{ng} / \mathrm{ml}$ klinik gebeliğin öngörülmesinde cut-off değeri olarak saptanmıştır. Serum AMH ve follikül sıvısı AMH seviyeleri ile implantasyon oranı arasında anlamlı pozitif korelasyon saptanmıstır $(\mathrm{r}=0.401$, $\mathrm{p}=0.008 ; \mathrm{r}=0.317, \mathrm{p}=0.039$ ). Serum ve follikül sıvısı AMH konsantrasyonları ve fertilizasyon oranları arasında anlamlı ilişki bulunmamıştır. Sonuç: Serum ve follikül sıvısı AMH konsantrasyonlanı implantasyon oranlanı ve klinik gebelik oranlanı ile ilişkilidir.

(J Turkish-German Gynecol Assoc 2012; 13: 21-6)

Anahtar kelimeler: AMH, E2, follikül sIvisı, IVF

Geliş Tarihi: 15 Eylül 2011

Kabul Tarihi: 19 Ekim 2011

\section{Introduction}

Anti-Mullerian hormone (AMH), a member of the transforming growth factor- $\beta$ (TGF- $\beta$ ) superfamily, is known to be derived from the granulosa cells of growing follicles (from the primary to the large antral follicle stage) (1). The TGF- $\beta$ superfamily members inhibin $\mathrm{A}$, inhibin $\mathrm{B}$, and activin are related to ovarian follicle development as well as $\mathrm{AMH}$, which is emerging as an important regulator of ovarian function, especially follicle selection and development $(1,2)$.
Serum basal AMH levels correlate with the number of antral follicles and age (3). Serum basal levels of AMH significantly decrease over time in young normoovulatory women, whereas other markers associated with ovarian aging do not change (4). AMH has been shown to inhibit FSH-induced follicle growth in female mice (5). The period of AMH production coincides with the period of oocyte meiotic arrest (6). Within the human ovary, AMH inhibits follicle recruitment and FSH-dependent follicle growth as well as selection $(2,7)$, and prevents depletion of the primordial follicle pool (8).

Address for Correspondence: Özlem Moraloğlu, Talatpaşa Bulvarı 158/5 Cebeci 06510 Ankara, Turkey

Phone: +90312362 7778 e.mail: ozlem.moraloglu@hotmail.com

(C) Copyright 2012 by the Turkish-German Gynecological Education and Research Foundation - Available online at www.jtgga.org doi:10.5152/jtgga.2011.71 
These inhibitory actions of AMH on early follicle development are overcome by the FSH treatment during in vitro fertilization (IVF). After gonadotropin treatment during IVF, the AMH concentrations in small and large antral follicles positively correlate with granulosa cell responsiveness to FSH (9).

Serum basal $\mathrm{AMH}$ concentrations are useful for predicting ovarian response in women undergoing IVF treatment (10); however, concerning the relationship between serum AMH levels and the pregnancy rates after assisted reproduction therapies, there are conflicting data in the literature. Some investigators (11-14) could not find a correlation between basal AMH levels and pregnancy, whereas others (15-18) observed a better prognostic value for clinical pregnancy than other available markers. The putative correlation of $\mathrm{AMH}$ in the follicular fluid (FF) and reproductive outcome has been investigated in several studies.

The aim of the present study was to investigate and compare the relationship of AMH and estradiol (E2) levels in serum and FF on the day of oocyte pick up (OPU) to the cycle parameters, prognostic parameters and the outcome of IVF treatment.

\section{Materials and Methods}

\section{Patient characteristics and IVF procedure}

Forty-three women aged between 18-40 years and undergoing IVF treatment were studied prospectively. Inclusion criteria included the presence of both ovaries, normal pretreatment hormonal status, and the absence of other endocrine pathologies, such as thyroid and adrenal disorders or hyperprolactinemia. Women with polycystic ovary syndrome were not included in the study. Informed consent was obtained from all women. The study was approved by the institutional review board of the hospital.

The long stimulation protocol was used in 37 (86\%) women; the microdose flare-up protocol was used in 6 (14\%) women. For the patients treated using the long protocol, pituitary downregulation was achieved by gonadotropin-releasing hormone (GnRH) agonist, leuprolide acetate (Lucrin daily injection, Abbott, Turkey). Gonadotropin stimulation was initiated on the third day of the subsequent withdrawal bleeding. For the patients treated using the microdose flare-up protocol, a GnRH agonist was administered starting on the $24^{\text {th }}$ day of the menstrual cycle, with the addition of gonadotropins on the $26^{\text {th }}$ day. Dose adjustments were performed on the $4^{\text {th }}$ day of stimulation and thereafter according to the sonographic findings and serum E2 levels. The women were administered human chorionic gonadotropin (HCG, Ovitrelle $250 \mathrm{mcg}$, Serono, Turkey) when at least 3 follicles had reached a diameter of $>18 \mathrm{~mm}$. Transvaginal oocyte retrieval was performed 36 hours later. All patients received luteal phase support of progesterone (Crinone 8\% vaginal gel, Serono, Turkey) daily starting from the day of the OPU. Intracytoplasmic sperm injection (ICSI) was performed for all patients. Fertilization was assessed using an established pronuclei (PN) scoring system. Embryos were transferred on day 3 or 5 after OPU. One or 2 embryos were transferred depending on the woman's age and embryo quality.
Embryo transfers were performed under transabdominal ultrasonographic guidance. Biochemical pregnancy was established when serum BHCG level > 20 IU/l was found on day 12 after embryo transfer. Clinical pregnancy was defined as a positive serum BHCG result with ultrasound evidence of a gestational sac and fetal heart beat at 6 weeks from the date of embryo transfer.

\section{Collection of serum and follicular fluid}

Blood samples were obtained on the day of OPU immediately before the procedure. Sera were obtained after centrifugation and stored at $-80^{\circ} \mathrm{C}$. Follicular fluid was obtained from the first retrieved follicle to avoid contamination of blood and flush medium. Care was taken to avoid contaminated samples. Follicular fluid samples were centrifuged for 15 minutes at 3000 rpm and stored at $-80^{\circ} \mathrm{C}$ before the analysis.

\section{Determination of AMH and E2 in serum and follicular fluid} Serum and FF AMH levels were determined by using an ultrasensitive ELISA (AMH ELISA kit; Diagnostic System Laboratories, Texas, USA). Results were expressed as ng/ ml. Serum and FF E2 concentrations were determined by an automated chemiluminescence technique (ADVIA Centaur CP, Tarrytown, USA).

\section{Statistical analysis}

Data analysis was performed using SPSS for Windows, version 11.5 (SPSS Inc., Chicago, IL, United States). Whether the distributions of continuous variables were normal or not was determined using the Shapiro-Wilk test. Continuous variables are expressed as mean \pm standard deviation or median (minimum-maximum), where applicable. The mean differences between groups were compared using Student's t-test. Otherwise, the Mann-Whitney U-test was applied for the evaluation of the median values. Degrees of associations between continuous variables were tested using Spearman's correlation analysis. Whether the effects of both serum and FF AMH on clinical pregnancy were statistically significant was evaluated by multiple logistic regression analysis adjustment for age and AFC. A p-value less than 0.05 was considered statistically significant.

\section{Results}

The study group consisted of 43 women with a mean age of $30.1 \pm 4.2$ years. Thirty-one patients $(72 \%)$ had unexplained infertility, and 12 patients (28\%) had male factor infertility. Clinical and cycle parameters and $\mathrm{FF}$ and serum concentrations of $\mathrm{AMH}$ and $\mathrm{E} 2$ of the patients with respect to the pregnancy outcome are shown in Table 1. No difference was observed between the groups that did or did not achieve clinical pregnancy with respect to age, BMI, baseline $\mathrm{E} 2, \mathrm{FSH}, \mathrm{AFC}$, amount of gonadotropin used, number of MII oocytes or fertilization rate. Serum AMH and FF AMH levels on the day of OPU were significantly increased in the group of women who achieved clinical pregnancy $(p=0.017, p=0.028)$. To investigate the correlation of 
Table 1. Clinical and cycle parameters, FF and serum concentrations

\begin{tabular}{|c|c|c|c|}
\hline Variables & $\begin{array}{l}\text { Clinical Pregnancy } \\
\qquad(n=14)\end{array}$ & $\begin{array}{l}\text { No pregnancy } \\
\quad(n=29)\end{array}$ & p value \\
\hline \multicolumn{4}{|l|}{ Clinical and cycle parameters } \\
\hline Age (years, mean \pm SD) & $29.3 \pm 4.4$ & $30.5 \pm 4.2$ & 0.249 \\
\hline $\mathrm{BMI}\left(\mathrm{kg} / \mathrm{m}^{2}\right.$, mean $\left.\pm \mathrm{SD}\right)$ & $24.4 \pm 3.7$ & $26.0 \pm 4.9$ & 0.299 \\
\hline Basal E2 (pg/ml,range) & $52.5(4-119)$ & $52(8-79)$ & 0.816 \\
\hline Basal FSH (lu/l, mean \pm SD) & $6.2 \pm 1.59$ & $6.6 \pm 2.65$ & 0.657 \\
\hline $\mathrm{AFC}$ (n, range) & $13(6-24)$ & $11(0-24)$ & 0.126 \\
\hline Dose of gonadotropins (IU, range) & $1225(900-4113)$ & $1872(600-7500)$ & 0.020 \\
\hline MII oocytes (n, range) & $7(2-15)$ & $7(1-16)$ & 0.516 \\
\hline Fertilization rate $(\%$, range $)$ & $63.3(9.1-100.0)$ & $50.0(12.5-100.0)$ & 0.567 \\
\hline \multicolumn{4}{|l|}{ FF hormone levels } \\
\hline AMH (ng/ml, range) & $4.1(0.35-13)$ & $1.87(0.32-16)$ & 0.028 \\
\hline $\mathrm{E} 2(\mathrm{pg} / \mathrm{ml}$, range $)$ & $544.6(171.7-849.8)$ & $422.2(16,6-1385.0)$ & 0.162 \\
\hline \multicolumn{4}{|c|}{ Serum hormone levels on the day of OPU } \\
\hline AMH (ng/ml, range) & $1.87(0.04-4.15)$ & $0.35(0.03-14)$ & 0.017 \\
\hline $\mathrm{E} 2$ (pg/ml, range) & $1118.5(59.1-2015.2)$ & $712.4(66.1-1984.1)$ & 0.058 \\
\hline
\end{tabular}

serum and FF AMH and clinical pregnancy, cut-off values were calculated using ROC analysis. For serum AMH, a cut-off level of $1.64 \mathrm{ng} / \mathrm{ml}$ was used to predict clinical pregnancy (sensitivity $71.4 \%$, specificity $69 \%$, positive predictive value $52.6 \%$, negative predictive value $83.3 \%$ ). For FF $\mathrm{AMH}$, a cut-off level of $3.8 \mathrm{ng} /$ $\mathrm{ml}$ (sensitivity $64.3 \%$, specificity $79.3 \%$, positive predictive value $60 \%$, negative predictive value $82.1 \%$ ) was used.

When multivariant logistic regression analysis was used for the prediction of clinical pregnancy, serum and FF AMH concentrations lost their statistical significance when adjusted for age and AFC. Serum and FF AMH were not the only independent factors for the prediction of clinical pregnancy.

Correlations between serum and FF AMH and E2 concentrations and clinical and hormonal parameters are shown in Table 2. Serum AMH concentrations were positively and significantly correlated with FF AMH concentrations $(r=0.638, \mathrm{p}<0.001)$. There was a significant positive correlation between serum $\mathrm{AMH}$ and E2 concentrations $(\mathrm{r}=0.429, \mathrm{p}=0.004)$. Significant positive associations were observed between serum AMH concentrations and $\mathrm{AFC}$, total number of oocytes retrieved, MII oocytes and implantation rate $(\mathrm{r}=0.476, \mathrm{p}<0.001 ; \mathrm{r}=0.343$, $\mathrm{p}=0.024 ; \mathrm{r}=0.389, \mathrm{p}=0.01 ;$ and $\mathrm{r}=0.401, \mathrm{p}=0.008$, respectively). However, negative correlations were observed between serum AMH levels, age and the amount of gonadotropins used $(\mathrm{r}=-0.311, \mathrm{p}=0.043 ; \mathrm{r}=-0.596, \mathrm{p}<0.001)$. FF AMH levels were significantly and positively correlated with AFC and implantation rate $(\mathrm{r}=0.343, \mathrm{p}=0.025 ; \mathrm{r}=0.317, \mathrm{p}=0.039)$ and negatively correlated with baseline FSH levels $(r=-0.333, p=0.029)$. No significant correlation was found between serum and FF AMH concentrations and fertilization rate.

\section{Discussion}

The assessment of the ovarian reserve before an IVF treatment is important to identify both poor- and high-responder patients. Poor ovarian reserve also predicts decreased fertility rates, although the relationship between declining ovarian reserve and decreased fertility rates remains incompletely understood (19). Several parameters have been proposed for the estimation of ovarian reserve including basal or clomiphene citrate-stimulated FSH levels, follicular phase inhibin B levels, ovarian volume, AFC and ovarian stromal blood flow. However, the associated predictive values remain controversial. In addition, it remains a challenge to identify young women with normo-ovulatory cycles but with a low ovarian reserve. Gnoth et al. demonstrated that AMH was an important screening test for reduced ovarian reserve in women. They proposed that, by using $\mathrm{AMH}$ levels $\leq 1.26 \mathrm{ng} / \mathrm{ml}$, it was possible to identify $97 \%$ of women with reduced ovarian reserve and predict low response to gonadotropin stimulation in $88 \%$ of cases in groups of comparable age (20). Consistent with the study by Wunder et al. a significant correlation of serum AMH levels with ovarian response as expressed by the number of oocytes retrieved is observed in the present study (21). In a study by Elgindy et al. that investigated longitudinal changes in AMH levels during different phases of the menstrual cycle in patients undergoing IVF treatment, no significant differences were found between $\mathrm{AMH}$ levels taken on day 3, on the day of ovulation and 7-8 days later (midluteal phase). The number of oocytes retrieved was found to be significantly correlated with midluteal $\mathrm{AMH}$, day $3 \mathrm{AMH}$ and ovulatory AMH (22). In addition, Fanchin et al. observed 
Table 2. Correlations between serum and FF AMH and E2 levels and clinical and hormonal parameters

\begin{tabular}{|c|c|c|c|c|c|c|c|c|}
\hline & \multicolumn{2}{|c|}{ FF AMH } & \multicolumn{2}{|c|}{ Serum AMH } & \multicolumn{2}{|c|}{ FF E2 } & \multicolumn{2}{|c|}{ Serum E2 } \\
\hline & $\mathbf{r}$ & $\mathbf{p}$ & $\mathbf{r}$ & $\mathbf{p}$ & $\mathbf{r}$ & $\mathbf{p}$ & $\mathbf{r}$ & $\mathbf{p}$ \\
\hline FF AMH & 1.000 & . & 0.638 & $<0.001$ & 0.218 & 0.161 & 0.062 & 0.694 \\
\hline Serum AMH on day of OPU & 0.638 & $<0.001$ & 1.000 & . & 0.170 & 0.275 & 0.429 & 0.004 \\
\hline FF E2 & 0.218 & 0.161 & 0.170 & 0.275 & 1.000 & . & 0.221 & 0.154 \\
\hline Serum E2 on day of OPU & 0.062 & 0.694 & 0.429 & 0.004 & 0.221 & 0.154 & 1.000 & . \\
\hline Age & -0.174 & 0.264 & -0.311 & 0.043 & 0.031 & 0.845 & -0.277 & 0.073 \\
\hline $\mathrm{AFC}$ & 0.343 & 0.025 & 0.476 & $<0.001$ & -0.171 & 0.273 & 0.165 & 0.291 \\
\hline Basal FSH & -0.333 & 0.029 & -0.281 & 0.068 & 0.184 & 0.236 & -0.065 & 0.679 \\
\hline Basal E2 & -0.062 & 0.695 & 0.056 & 0.723 & 0.142 & 0.363 & 0.214 & 0.168 \\
\hline Dose of gonadotropins & -0.264 & 0.087 & -0.596 & $<0.001$ & -0.087 & 0.579 & -0.376 & 0.013 \\
\hline Total oocytes retrieved & 0.072 & 0.647 & 0.343 & 0.024 & 0.072 & 0.648 & 0.568 & $<0.001$ \\
\hline MII oocytes & 0.143 & 0.361 & 0.389 & 0.010 & 0.055 & 0.725 & 0.586 & $<0.001$ \\
\hline Fertilization rate & -0.148 & 0.344 & 0.029 & 0.854 & 0.047 & 0.767 & 0.125 & 0.424 \\
\hline Implantation rate & 0.317 & 0.039 & 0.401 & 0.008 & 0.136 & 0.386 & 0.239 & 0.123 \\
\hline
\end{tabular}

a remarkable lack of variation of serum AMH levels between two distinct points in the menstrual cycle (day 3 and the day of OPU), showing that AMH levels remain stable throughout the cycle independent of FSH $(9,23)$. Our results, together with those of other studies in the literature, support the assumption that serum AMH levels can predict the number of oocytes that will be yielded by an IVF cycle. We also found a positive correlation between serum AMH and serum E2: the expected serum E2 concentrations are associated with the number of oocytes retrieved.

With respect to fertilization, we did not find a significant association between fertilization rate and serum or FF AMH levels. This finding is consistent with some, but not all, studies in the literature. Takahashi et al. (24) reported that the FF AMH levels of fertilized patients were 3.42 times higher than those of nonfertilized patients. However, they found no correlation between serum AMH and high-quality embryos. These results indicate that serum AMH levels did not reflect high-quality fertilization. In a study by Silberstein et al. (25), which included 257 patients, the authors found that AMH levels at the time of HCG administration reflect both ovarian reserve and better embryo morphology. However, Fanchin et al. and Wunder et al. $(9,21)$ found similar fertilization rates regardless of the $\mathrm{AMH}$ concentrations in serum or FF. Due to contradictory reports regarding fertilization, oocyte quality and embryo morphology in the literature, these issues deserve further investigation.

The results of this study indicate that serum and FF AMH levels are good predictors of implantation and clinical pregnancy. Cut-off values for both serum and FF AMH were calculated for the prediction of clinical pregnancy. Cut-off concentrations for serum $\mathrm{AMH}$ and $\mathrm{FF}$ AMH were found to be $1.64 \mathrm{ng} / \mathrm{ml}$ (71.4\% sensitivity, specificity $69 \%)$ and $3.8 \mathrm{ng} / \mathrm{ml}(64.3 \%$ sensitivity, $79.3 \%$ specificity), respectively. High FF AMH levels constitute a useful marker for implantation. FF AMH concentrations reflect granulosa cell functioning. It is postulated that granulosa cell metabolism and embryogenic competence of the oocyte are interrelated (9). FF AMH concentrations on the day of OPU may contribute to embryo quality, which in turn yields competent embryos with high implantation potential, and thus results in a high probability of pregnancy. Our results are consistent with the results of a study by Fanchin et al. (9) They found that high clinical pregnancy and implantation rates correlated with FF AMH levels and concluded that FF $\mathrm{AMH}$ measurements could help to identify the embryos that are most likely to achieve implantation in IVF cycles. Silberstein et al. (25) found that AMH levels at the time of HCG administration ( $\geq 2.7 \mathrm{ng} / \mathrm{ml}$ ) portended improved oocyte quality as reflected by higher implantation rates and a trend toward improved clinical pregnancy rate. In the study by Nelson et al. (26), which investigated the value of serum AMH in the prediction of live birth and ovarian response to stimulation, it was found that plasma $\mathrm{AMH}$ is an accurate predictor of live birth and strongly correlated to the risk of excessive response to ovarian stimulation.

There are several clinical implications of these findings. Serum AMH seems to be a predictor of ovarian reserve as represented by oocyte yield in IVF cycles. This may allow development of individualized and optimized treatment strategies prior to the first cycle of ovarian stimulation. It is also important for the counseling of couples for making decisions after a failed IVF cycle, especially in patients with low ovarian reserves. 
Recent studies have shown that a low response to ovulation induction is associated with early menopause (20, 27, 28). $\mathrm{AMH}$ seems to be a promising parameter for the occurrence of menopausal transition $(20,29)$. Thus, AMH may serve as a screening test for diminished ovarian reserve, especially in patients with regular cycles (3).

The results of our study, which were confirmed by the study of Wunder et al. (21), demonstrated a positive correlation between serum and FF AMH concentrations. A finer determination of $\mathrm{AMH}$ in $\mathrm{FF}$ is not necessary because serum concentrations of AMH yield similar data.

Because FF AMH concentrations are positively correlated with implantation and clinical pregnancy rates, FF AMH measurement during embryo transfer may be an additional parameter aside from embryo morphology with which to distinguish the embryos that are most likely to achieve implantation and thus clinical pregnancy.

In conclusion, the results of the study indicate that serum $\mathrm{AMH}$ and FF AMH concentrations are positively correlated with implantation and clinical pregnancy rates. In addition, serum $\mathrm{AMH}$ concentrations are associated with the number of oocytes and the number of mature oocytes retrieved.

\section{Conflict of interest}

No conflict of interest was declared by the authors.

\section{References}

1. Weenen C, Laven JS, Von Bergh AR, Cranfield M, Groome NP, Visser JA, et al. Anti - Müllerian hormone expression pattern in the human ovary: potential implications for initial and cyclic follicle recruitment. Mol Hum Reprod 2004; 10: 77-83. [CrossRef]

2. Knight PG, Glister C. TGF-beta superfamily members and ovarian follicle development. Reproduction 2006; 132: 191-206. [CrossRef]

3. Göksedef BP, Idiş N, Görgen H, Rüstemoğlu AY, Api M, Çetin A. The correlation of the antral follicle count and serum anti-mullerian hormone. J Turkish-German Gynecol Assoc 2010; 11: 212-5. [CrossRef]

4. de Vet A, Laven JS, de Jong FH, Themmen AP, Fauser BC. Antimüllerian hormone serum levels: a putative marker for ovarian aging. Fertil Steril 2002; 77: 357-62. [CrossRef]

5. Durlinger AL, Gruijters MJ, Kramer P, Karels B, Kumar TR, Matzuk $\mathrm{MM}$, et al. Anti-Müllerian hormone attenuates the effects of FSH on follicle development in the mouse ovary. Endocrinology 2001; 142: 4891-9. [CrossRef]

6. Ueno S, Kuroda T, Maclaughlin DT, Ragin RC, Manganaro TF, Donahoe PK. Mullerian inhibiting substance in the adult rat ovary during various stages of the estrous cycle. Endocrinology 1989; 125: 1060-6. [CrossRef]

7. Seifer DB, Maclaughlin DT. Mullerian Inhibiting Substance in an ovarian growth factor emerging clinical significance. Fertil Steril 2007; 88: 539-46. [CrossRef]

8. Themmen AP. Anti-mullerian hormone: its role in follicular growth initiation and survival and as an ovarian reserve marker. J Natl Cancer Inst Monogr 2005; 34: 18-21. [CrossRef]

9. Fanchin R, Mendez Lozano DH, Frydman N, Gougeon A, di Clemente N, Frydman R, et al. Anti-Müllerian hormone concentrations in the follicular fluid of the preovulatory follicle are predictive of the implantation potential of the ensuing embryo obtained by in vitro fertilization. J Clin Endocrinol Metab 2007; 92: 1796-802. [CrossRef]

10. Ebner T, Sommergruber M, Moser M, Shebl O, Schreier-Lechner E, Tews G. Basal level of anti-Müllerian hormone is associated with oocyte quality in stimulated cycles. Hum Reprod 2006; 21: 2022-6. [CrossRef]

11. Peñarrubia J, Fábregues F, Manau D, Creus M, Casals G, Casamitjana R, et al. Basal and stimulation day 5 anti-Mullerian hormone serum concentrations as predictors of ovarian response and pregnancy in assisted reproductive technology cycles stimulated with gonadotropin-releasing hormone agonistgonadotropin treatment. Hum Reprod 2005; 20: 915-22.

12. Fiçicioglu C, Kutlu T, Baglam E, Bakacak Z. Early follicular antimüllerian hormone as an indicator of ovarian reserve. Fertil Steril 2006; 85: 592-6. [CrossRef]

13. Laven JS, Mulders AG, Visser JA, Themmen AP, De Jong FH, Fauser BC. Anti-Müllerian hormone serum concentrations in normoovulatory and anovulatory women of reproductive age. J Clin Endocrinol Metab 2004; 89: 318-23. [CrossRef]

14. Lekamge DN, Barry M, Kolo M, Lane M, Gilchrist RB, Tremellen KP. Anti-Müllerian hormone as a predictor of IVF outcome. Reprod Biomed Online 2007; 14: 602-10. [CrossRef]

15. Smeenk JM, Sweep FC, Zielhuis GA, Kremer JA, Thomas CM, Braat DD. Antimüllerian hormone predicts ovarian responsiveness, but not embryo quality or pregnancy, after in vitro fertilization or intracyoplasmic sperm injection. Fertil Steril 2007; 87: 223-6. [CrossRef]

16. Eldar-Geva T, Ben-Chetrit A, Spitz IM, Rabinowitz R, Markowitz E, Mimoni T, et al. Dynamic assays of inhibin B, anti-Mullerian hormone and estradiol following FSH stimulation and ovarian ultrasonography as predictors of IVF outcome. Hum Reprod 2005; 20: 3178-83. [CrossRef]

17. Wu CH, Chen YC, Wu HH, Yang JG, Chang YJ, Tsai HD. Serum antiMüllerian hormone predicts ovarian response and cycle outcome in IVF patients. J Assist Reprod Genet 2009; 26: 383-9. [CrossRef]

18. Kini S, Li HW, Morrell D, Pickering S, Thong KJ. Anti-mullerian hormone and cumulative pregnancy outcome in in-vitro fertilization. J Assist Reprod Genet 2010; 27: 449-56. [CrossRef]

19. Bancsi LF, Broekmans FJ, Eijkemans MJ, de Jong FH, Habbema JD, te Velde ER. Predictors of poor ovarian response in in vitro fertilization: a prospective study comparing basal markers of ovarian reserve. Fertil Steril 2002; 77: 328-36. [CrossRef]

20. Gnoth C, Schuring AN, Friol K, Tigges J, Mallmann P, Godehardt E. Relevance of anti-Mullerian hormone measurement in a routine IVF program. Hum Reprod 2008; 23: 1359-65. [CrossRef]

21. Wunder DM, Guibourdenche J, Birkhäuser MH, Bersinger NA. Anti-Müllerian hormone and inhibin B as predictors of pregnancy after treatment by in vitro fertilization/intracytoplasmic sperm injection. Fertil Steril 2008; 90: 2203-10. [CrossRef]

22. Elgindy EA, El-Haieg DO, El-Sebaey A. Anti-Müllerian hormone: correlation of early follicular, ovulatory and midluteal levels with ovarian response and cycle outcome in intracytoplasmic sperm injection patients. Fertil Steril 2008; 89: 1670-6. [CrossRef]

23. Bath LE, Wallace WH, Shaw MP, Fitzpatrick C, Anderson RA. Depletion of ovarian reserve in young women after treatment for cancer in childhood: detection by anti-Müllerian hormone, inhibin B and ovarian ultrasound. Hum Reprod 2003; 18: 2368-74. [CrossRef]

24. Takahashi C, Fujito A, Kazuka M, Sugiyama R, Ito H, Isaka K. AntiMüllerian hormone substance from follicular fluid is positively associated with success in oocyte fertilization during in vitro fertilization. Fertil Steril 2008; 89: 586-91. [CrossRef] 
25. Silberstein T, MacLaughlin DT, Shai I, Trimarchi JR, LambertMesserlian G, Seifer DB, et al. Mullerian inhibiting substance levels at the time of HCG administration in IVF cycles predict both ovarian reserve and embryo morphology. Hum Reprod 2006; 21 : 159-63. [CrossRef]

26. Nelson SM, Yates RW, Fleming R. Serum anti-Müllerian hormone and FSH: prediction of live birth and extremes of response in stimulated cycles--implications for individualization of therapy. Hum Reprod 2007; 22: 2414-21. [CrossRef]

27. Nikolaou D, Lavery S, Turner C, Margara R, Trew G. Is there a link between an extremely poor response to ovarian hyperstimula- tion and early ovarian failure? Hum Reprod 2002; 17: 1106-11. [CrossRef]

28. Lawson R, El-Toukhy T, Kassab A, Taylor A, Braude P, Parsons J, et al. Poor response to ovulation induction is a stronger predictor of early menopause than elevated basal FSH: a life table analysis. Hum Reprod 2003; 18: 527-33. [CrossRef]

29. Van Rooij IA, Broekmans FJ, Scheffer GJ, Looman CW, Habbema JD, de Jong FH, et al. Serum antimullerian hormone levels best reflect the reproductive decline with age in normal women with proven fertility: a longitudinal study. Fertil Steril 2005; 83: 979-87. [CrossRef] 